\title{
補體結合性抗元產生孝條件こする鼻疽菌 の發育要素に就て
}

\author{
岩下 光之 \\ (大連渾鐵衞生研究所)
}

\section{ON THE NUTRITIVE FACTORS FOR THE GROWTH OF BACILLUS MALLEI, WITH SPECIAL REFERENCE TO PRODUCTION OF ANTIGEN FOR COMPLIMENT-FIXATION.}

\author{
M. IWASHITA. \\ (From the Hygienic Institute, S. M. R. Co, \\ Dairen, Manchukuo.)
}

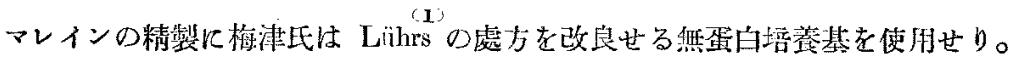

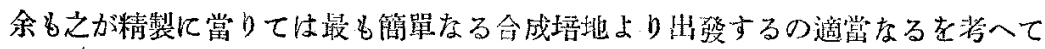

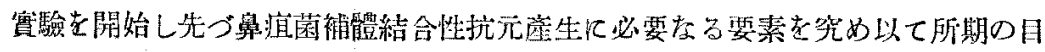

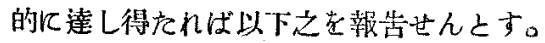

\section{I. 蛽驗材料及び方法}

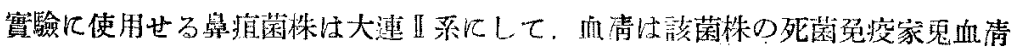
なり

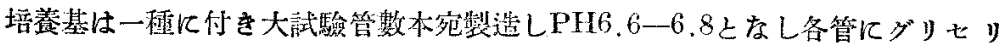

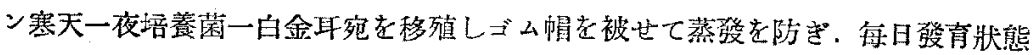




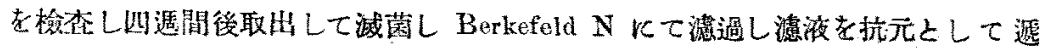

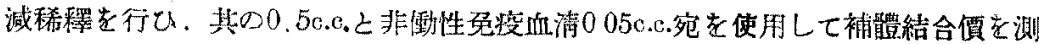
定せり。

\section{II. 各種了ミノ酸の比較}

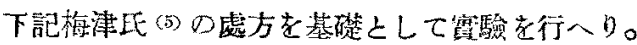

\begin{tabular}{|c|c|c|}
\hline 第了橉酸加里 & 15.0 & 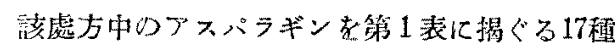 \\
\hline 第 1 燐酸曹澾 & 20.0 & ノ酸比て代用し、 \\
\hline 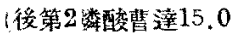 & 女めたり & 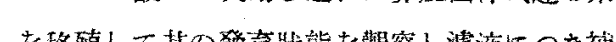 \\
\hline 硫酸、少京シウム & 12.5 & 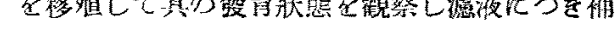 \\
\hline グリセりン & 100.0 & 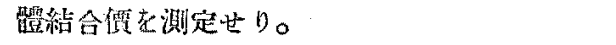 \\
\hline アスバラギン & 25.0 & \\
\hline 硫酸アムモニウム & 40.0 & \\
\hline 硫酸鐵ソムモニウム & 0.05 & \\
\hline 蒸溜水 & 500.0 & \\
\hline
\end{tabular}

第 1 域

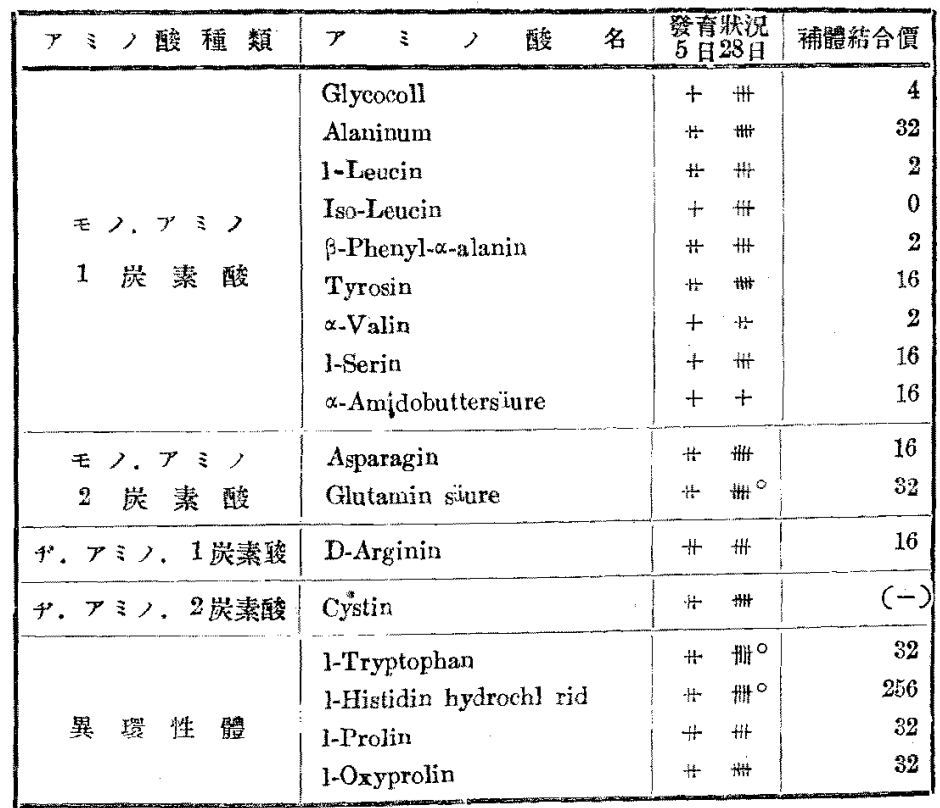




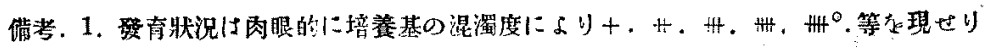

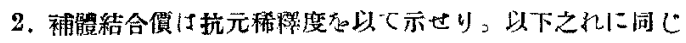

此の結果によれば菌發育と抗元性とは大體に於て本行するも常に必剠し平行 するものに非るが如し。例へば發育相掌に传良なる Glycocoll, Loucin, Iso-Lencin,

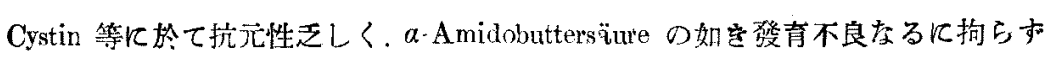
抗元性に䈏むものあるが如し。而してモノ、アミノ1炭素酸に屈するbのは成績 不同なるも概して良好なるは異環性体に屬するるのにして特に L-Histidin hydrochlorid は断然優良なる成績を示せり。

\section{III. アミノ酸以外の要素}

前䖪驗によりアミ，酸中にては Histidin 最優良なる絬果を與ふるを知る。然 らば Histidin 骂一江て如何をる發育を是し得るや，或は他の要素の配合を必要

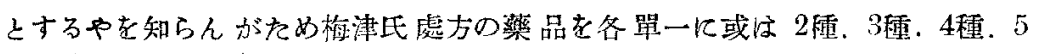

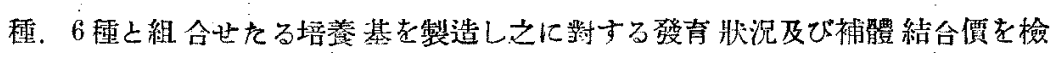
せり。

第 2 表

\begin{tabular}{|c|c|c|c|}
\hline 仴会せ & 藥 & $\begin{array}{l}\text { 登育狀況 } \\
5 \text { 日:8日 }\end{array}$ & $\begin{array}{l}\text { 補 能 } \\
\text { 結合價 }\end{array}$ \\
\hline 1 種制 & Histidin & \pm \pm & 2 \\
\hline 2 種類 & Gly. Hist. & $H .+4$ & 4 \\
\hline 3 䅜類 & $\begin{array}{l}\text { 1. 第 } 1 \text { 燐加，第 } 2 \text { 燐曹. Gly. } \\
\text { 口. 第 } 1 \text { 燐加，第 } 2 \text { 燐啬. Hist. }\end{array}$ & $\begin{array}{l}- \\
+ \\
+\end{array}$ & $\begin{array}{r}(-) \\
8\end{array}$ \\
\hline 4. 種類 & 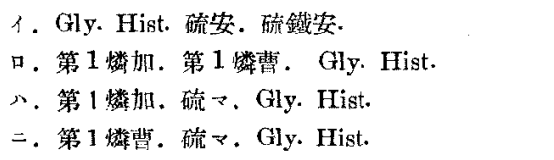 & $\begin{array}{l}+\quad+ \\
+4 \\
+4 \\
+\quad+4\end{array}$ & $\begin{array}{r}(-) \\
32 \\
16 \\
8\end{array}$ \\
\hline 5 種類 & 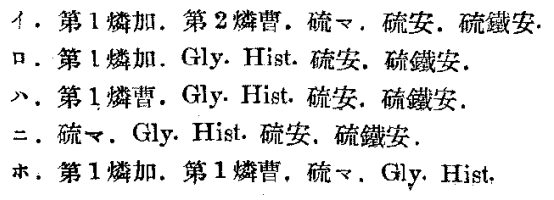 & 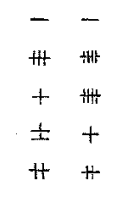 & $\begin{array}{r}(-) \\
8 \\
16 \\
(-) \\
16\end{array}$ \\
\hline
\end{tabular}




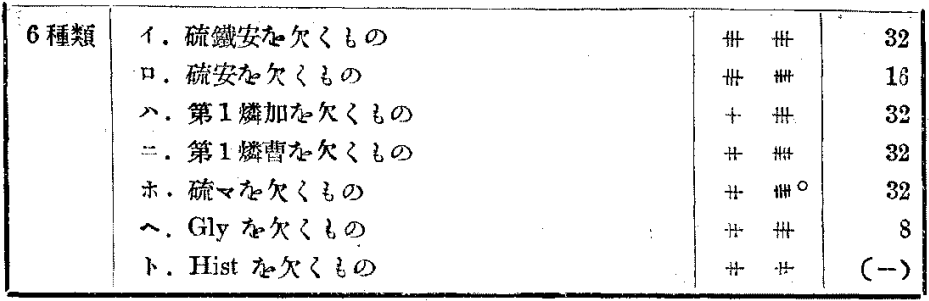

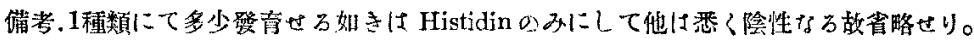

6 種樂品混合唔養基即ち梅津處方 7 種藥品中の 1 種を除去吶るものの中 Histidin を欠くものは稍菌の發有を見るも抗元性考をを示し. Glycerin を欠くもの之

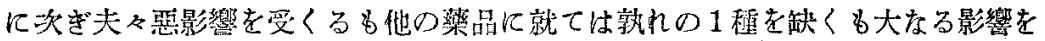
認めず。

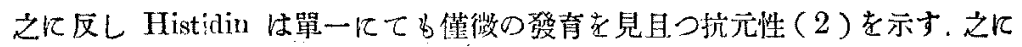

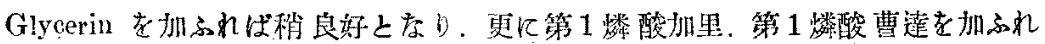
ば發育は最良索らざれど其の抗元性優是疗るを示す。之により余の補體結合性抗 元座生の目的比

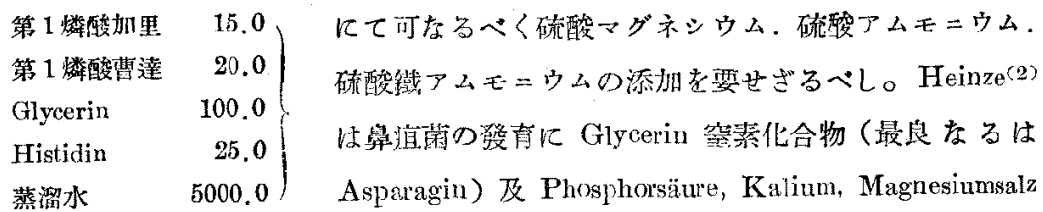

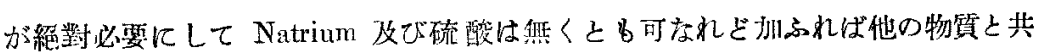

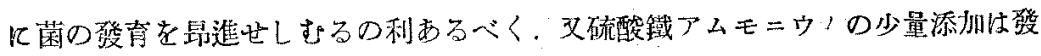

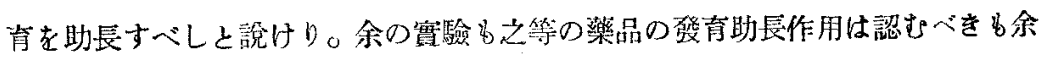

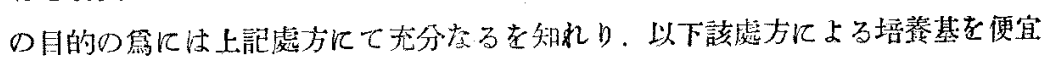

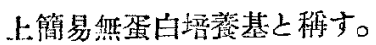

\section{Amino 酸の代用品}

Amino 酸を Amino 基子缺除せる有機酸にて代用して菌の墢育を認め得るや

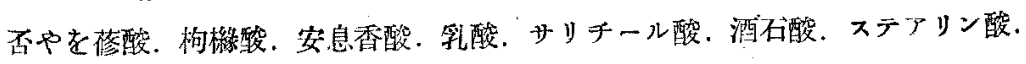

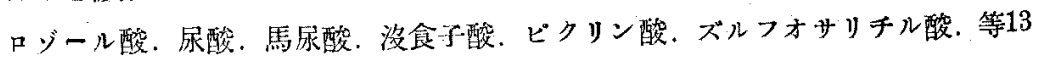




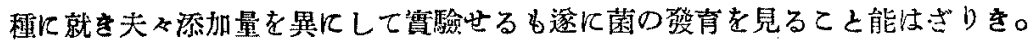

\section{V. 簡易無蛋白培養基の好適水素イオン濃度}

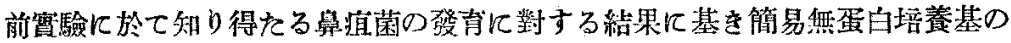

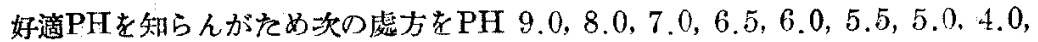

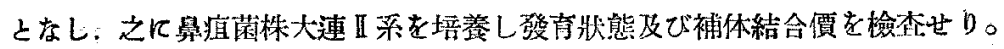

\begin{tabular}{|c|c|}
\hline 第 1 磷酸加里 & 15.0 \\
\hline 第 2 燐酰霄澾 & 15.0 \\
\hline グท七yン & 100.0 \\
\hline ヒスキギン & 25.0 \\
\hline 聴溜水 & 5000.0 \\
\hline
\end{tabular}

第 3 表

\begin{tabular}{|c|c|c|c|}
\hline${ }_{\text {FH }}^{\text {起 始 }}$ & 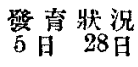 & $\begin{array}{l}\text { 補 艝 } \\
\text { 結合價 }\end{array}$ & 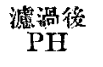 \\
\hline 9.0 & $-\quad-$ & 0 & \\
\hline 8.0 & \pm & 8 & 7.3 \\
\hline 70 & $H$ & 32 & 6.8 \\
\hline 6.5 & H & 16 & 6.2 \\
\hline 6.0 & 世 & 8 & 6.0 \\
\hline 5.5 & H & $(-)$ & 5.5 \\
\hline 5.0 & - & $(-)$ & 4.7 \\
\hline 4.0 & - & $(-)$ & 4.0 \\
\hline
\end{tabular}

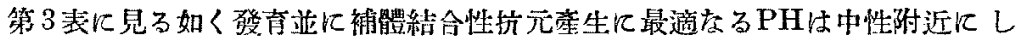
てPH 8.0以上及び5.0以下は菌の墢有に適せす。

之れ余等が嘗つて Bouillon 及び Peptou 水にて害驗せる發育PH域と一致す。 然れども培養後Bouillon に於て10日後. Pepton 水に於て5日後頃上り夫↔ PHは アルカリに向ひ 4 週後には各PH8.0以上之なり菌は死隇せり．而して此の死隇は

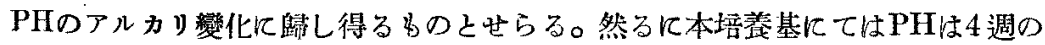
最徯迄大なる變化なく從つて菌の死減を結果するてとなし。

\section{Glycerin 及び Histidin の適量}

簡易培食基に添加すへき Glycerin 及 Histidin の喵量を檢定せるに Glycerin は本菌の發育に對し量的に大なる影響なをも Histidin は 0.5-1.0\%を最滴と し. 以下の量にては漸次發育不良となるが如し。 
第 4 表

\begin{tabular}{|c|c|c|c|}
\hline $\begin{array}{c}\text { Glycerin } \\
\text { of }\end{array}$ & 嬁青 & 然況 & $\begin{array}{l}\text { 䋠 體 } \\
\text { 結合贘 }\end{array}$ \\
\hline 5,0 & + & \# & 16 \\
\hline 2.0 & + & 开 & 8 \\
\hline 1.0 & $H$ & \# & 16 \\
\hline 0.5 & + & $H$ & 8 \\
\hline 0 & + & \# & 8 \\
\hline
\end{tabular}

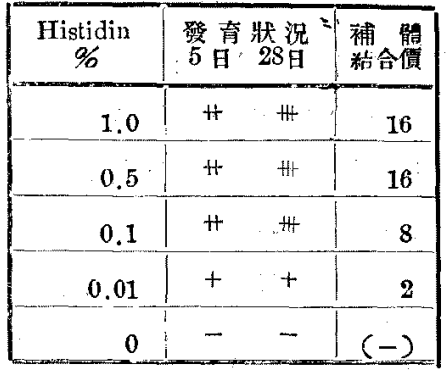

\section{VII，簡易培養基に於ける鼻瘨菌各株の弡育と補體結合覔}

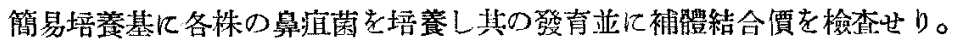

第 5 表

\begin{tabular}{|c|c|c|}
\hline 菌 株 名 & $\begin{array}{c}\text { 發青狀況 } \\
5 \text { 日28日 }\end{array}$ & $\begin{array}{l}\text { 補 融 } \\
\text { 結合價 }\end{array}$ \\
\hline 1. 大連I系 & +4 & 32 \\
\hline \&, " II 系 & $H \quad H$ & 32 \\
\hline 3. " $\mathbb{E}$ 係 & $H \quad H$ & 32 \\
\hline 4." $\mathrm{N}$ 系 & +4 & 32 \\
\hline 5. 釜仙 & $\pm H$ & 32 \\
\hline 6，唒袁城 & $H \quad H$ & 16 \\
\hline 7. 留十七 & $\# \#$ & 16 \\
\hline 8. 政相十八 & $H+H$ & 32 \\
\hline 9. 吉 & $H \quad H$ & 16 \\
\hline 10. 奉 & +4 & 32 \\
\hline 11. 公尘嶺 & $H \quad H$ & 32 \\
\hline 12、競馬馬 & $\because \quad H$ & 64 \\
\hline 13. 歐 洲 & +4 & 32 \\
\hline 14. 155 & H. \# & 32 \\
\hline
\end{tabular}

左表に示す如く各菌株共本培䓹基に 同㥞疗る發育去存し，補體絈合價为 6 一64倍を示せり。依て目的によりては 本培養基萑充分使用し得へむものなる を信ぜしむ。

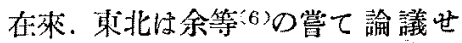
当所謂鞑毛性鼻疽菌(圾本氏 ferella Parawhitmori なる名稱を附與 せん事を提唱せる菌）にして此の2柔 は本培養基沉てb他畨に比し發青不良 にして大連】系血清に對し補䯏絬合性

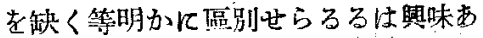
る事筫なりとす。 


\begin{tabular}{|ccc|cc|c|}
\hline 15.1 & 6 & 3 & $\#$ & $\#$ & 32 \\
\hline 16. 在 & 來 & $\#$ & + & $(-)$ \\
\hline 17. 東 & 北 & +++ & $(-)$ \\
\hline
\end{tabular}

\section{VIII. 總括}

1. 梅津氏培養基の Asparagin を各種（17種）のAmino 酸を以て代用せる

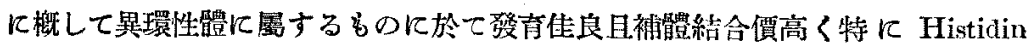
は断然好成續を示す。

2. 梅津氏培養基の處方藥品 7 種中重要性を試驗せるに Histidin 忙缺くへ からざるのにして單に Histidin 水中にても稍墢育の狀を見る。えに Glycerin, 第 1 燐酸加里. 第 2 燐酸曹澾（邓は第 1燐酸曹澾）を處方寸れば菌の發育、補體 結合價共に梅津氏培基に劣らざるものと認む。

3.Amino 酸を除をて各種有機酸を種々の量に加ふるも逐に發育を見ること 能はざりを。

4. Glycerin 量は 0.5-5\%にて大なる影響は來さざるも Histidin は0.1-1 \%を要すべし。

5. 簡易無蛋白培養基に於ける鼻㨁囷の發育PH 域法 5.5-8.0にして最適 $\mathrm{PH}$ は6.5-7.0なりとす。

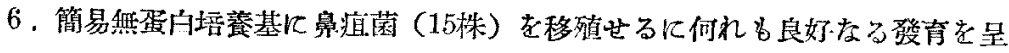
L. 且つ補體結合性抗元老有す。

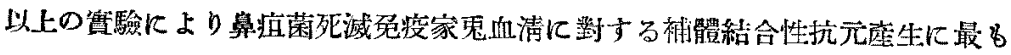
適すべき簡單なる培養基（簡易無蛋的培養基）の組成は

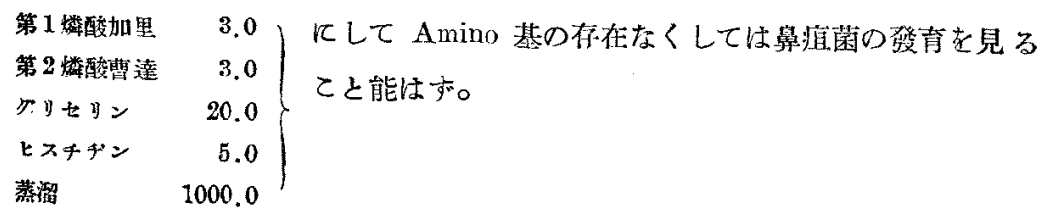

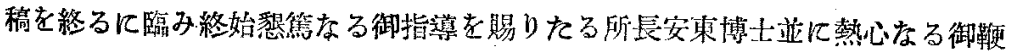
落を受けをる科辰笠井博士に感謝す。 
उ a

1. Lührs; Z. f. Veterkd. Bd. 29. S. $253 . \quad$ (bandb. d. Path. Mi org. Kolle, Kraus, $)$

2. Heinze; Diss. Berlin. 1921 (同上)

3. Vehse; Mh. Tierhlk. 1920 Bd. 31. S. 363. (同上)

4. Löwenstein u. Pick; Biochem. Z. 1911. Bd. 31. S. 142 (同上)

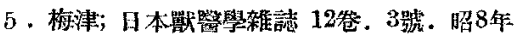

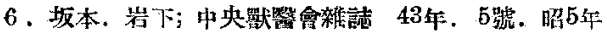

7 . 坂本; 同 45年. 9 號. 昭7年 